\title{
Um manuscrito inédito do naturalista Manuel Ferreira da Câmara: "Nota sobre a extração das minas do Principado da Transilvânia" (1796)
}

\author{
An unpublished manuscript of naturalist Manuel Ferreira da \\ Câmara: "A note on extraction from the mines of the Principality \\ of Transylvania" (1796)
}

\author{
Alex Gonçalves Varela \\ Bolsista PCI de Pós-doutorado do \\ Museu de Astronomia e Ciências \\ Afins/Ministério da Ciência e \\ Tecnologia \\ Rua Ferreira Viana, 36/502 \\ 22210-040 - Rio de Janeiro - RJ - \\ Brasil \\ alex@mast.br
}

VARELA, Alex Gonçalves. Um manuscrito inédito do naturalista Manuel Ferreira da Câmara: "Nota sobre a extração das minas do Principado da Transilvânia (1796). História, Ciências, Saúde Manguinhos, Rio de Janeiro, v.17, n.1, jan.-mar. 2010, p.185-201.

\section{Resumo}

O personagem Manuel Ferreira da Câmara foi um dos expoentes da Ilustração luso-americana. A historiografia deu destaque às suas atividades como administrador, funcionário e político, deixando de incorporar a dimensão de naturalista. Ao recuperar essa faceta de estudioso do mundo natural, encontramos em arquivos e bibliotecas diversos textos do autor que permanecem inéditos. Um deles tem como título "Nota sobre a extração das minas do Principado da Transilvânia escrita em Zalathna aos 5 de março de 1796", produzido no âmbito da viagem realizada por diversos países da Europa central e setentrional, a pedido do governo português. Dada a reflexão elaborada por Câmara sobre a região da Transilvânia e a política de administração das minas ali implementada, é de grande relevância a sua publicação.

Palavras-chave: História das ciências; Manuel Ferreira da Câmara; Ilustração luso-americana; Transilvânia; mineração.

\section{Abstract}

Manuel Ferreira da Câmara was one of the exponents of Luso-american Enlightenment. The historiography has highlighted his activities as an administrator, employee and politician, neglecting to incorporate his dimension as a naturalist. By resurrecting this facet of a student of the natural world, we find in the archives and libraries various texts by the author that remain unpublished. One of these manuscripts is entitled "A note on extraction from the mines of the Principality of Transylvania written in Zalathna on March 5 , 1796", produced during a trip through several countries of Central and Northern Europe at the request of the Portuguese government. Given the reflection elaborated by Câmara on the Transylvania region and the policy of administering the mines implemented there, its publication is highly relevant.

Keywords: history of the sciences; Manuel Ferreira da Câmara; Luso-american Enlightenment; Transylvania; mining. 
A presença do ilustrado Manuel Ferreira da Câmara Bethencourt Aguiar e Sá na bibliografia especializada se dá devido a seu perfil de político, evidenciando sua atuação como parlamentar. Tais análises dão relevância à atuação do personagem no período da independência do Brasil, quando atuou como deputado na Assembléia Nacional Constituinte de 1823 e como senador por Minas Gerais, no período de 1827 a 1835 . Um exemplo desse tipo de enfoque, que enfatiza exclusivamente o viés político de sua trajetória histórica, é o artigo de Sigaud (1842).

No entanto, Manuel Ferreira da Câmara notabilizou-se não apenas como homem público, mas também como estudioso e pesquisador do mundo natural. Em sua trajetória histórica, a face de naturalista e os interesses políticos são indissociáveis, fato que caracteriza o homem ilustrado do século XVIII. Exemplo mais relevante dessa associação entre interesses científicos e políticos foi o do francês Antoine Laurent Lavoisier (1743-1794) que atuou ao mesmo tempo como químico e fermier général, coletor de impostos do Antigo Regime francês (Bensaude-Vincent, 1996). Não são duas carreiras diferentes ou sucessivas, mas sim dois perfis de uma mesma trajetória de vida que não podem ser, de forma alguma, cindidos: o de estudioso das ciências naturais e o de homem público. Portanto, há lacunas que estimulam a reflexão sobre o personagem em novas direções.

Câmara nasceu em Minas Gerais, muito provavelmente em Santo Antônio de Itacambira, em territórios da Demarcação Diamantina, por volta de 1764. Fez parte de uma geração de ilustrados luso-americanos formados na Universidade de Coimbra reformada pelo marquês de Pombal. O estudioso juntou-se às elites cultas da metrópole matriculando-se em Coimbra, em 1783, no curso de Leis. No ano seguinte, passou a cursar também o de Filosofia Natural. Tornou-se bacharel em leis e filosofia em 1787 e obteve o diploma em junho de 1788.

Após a conclusão do curso superior em Coimbra, Câmara permaneceu em Portugal, sendo eleito membro da Academia Real das Ciências de Lisboa em 1789. No espaço da Academia, Câmara despertou a atenção de alguns membros, entre os quais o duque de Lafões. Como resultado da admiração desse nobre, ganhou uma bolsa de estudos do governo português para uma viagem científica de formação teórica e prática no campo da metalurgia e da mineração, por diversos países da Europa central e setentrional, juntamente com Joaquim Pedro Fragoso e José Bonifácio de Andrada e Silva.

Um dos locais onde Câmara esteve foi a região da Transilvânia, importante centro europeu de tradição de exploração de metais nobres. Naquela região, elaborou o texto intitulado "Nota sobre a extração das minas do Principado da Transilvânia escrita em Zalathna aos cinco dias do mês de março de 1796", que permaneceu manuscrito até os nossos dias, no Arquivo Nacional da Torre do Tombo, em Portugal. De acordo com Pinto (2003), as razões que fizeram Câmara viajar para Zalathna e visitar a Transilvânia, passando lá o inverno de 1795/1796, foram o excelente conceito das técnicas de fundição lá praticadas; o interesse em estudar a administração das atividades de mineração e compará-la com aquelas feitas no Brasil; e a localização da administração geral da Transilvânia, centrada em Zalathna. Ainda segundo o mesmo autor, por ocasião da visita de Câmara, o soberano Habsburgo era Leopoldo II; a Transilvânia estava sob dominação austríaca desde a ocupação por Leopoldo I, em 1691. 
A primeira parte do estudo de Câmara versa sobre a legislação mineira e a administração das minas nos Estados austríacos, que tinha como base a alemã. Câmara deu relevância aos seguintes pontos: o direito de extrair minas pertencia à competência do soberano; o imperador poderia conceder o direito a qualquer um, para explorar as minas, como também era obrigado a ajudar e socorrer às companhias mineiras; cada região mineira seria administrada por um conselho comandado pelo soberano; a administração dos bosques estava unida ao conselho das minas; os 'corpos de minas' eram independentes de qualquer jurisdição civil ou política; e havia um Conselho de Finanças, que tinha a seu cargo a administração e inspeção das minas e cujos conselheiros eram instruídos na arte das minas e na economia montanhística.

Em seguida, Câmara informa detalhadamente as "diferentes partes da administração montanhística da Transilvânia", mencionando os diversos metais extraídos e a importância que o soberano atribuía a cada um em particular. O naturalista também fornece detalhes sobre os corpos institucionais da administração das minas nos Estados austríacos e na Transilvânia em particular. E, em diversos trechos do estudo, faz referências à mineração na América portuguesa e em Portugal, a título de sugestões à rainha dona Maria I naquilo que deveria ser feito quanto à administração e melhoria das técnicas de mineração.

Para Câmara, a viagem foi imprescindível na sua especialização como naturalista. Ele tornou-se, como afirmava, 'metalurgista de profissão'. Ao retornar a Portugal, em 1798, foi contratado pelo Estado português como consultor do governo em assuntos de minas e metalurgia (Pinto, 1994). Acima de tudo, era um fiel vassalo da monarquia dos Braganças, comungando uma 'identidade política coletiva' que remetia ao Estado português (Jancsó, Pimenta, 2000).

Câmara foi arregimentado por dom Rodrigo para assumir postos importantes na administração central do Império português, para aplicação firme e eficiente de sua política reformista. Foi enviado para a América portuguesa, mais precisamente para a região de Minas Gerais, para desempenhar a função de intendente geral das minas na capitania de Minas Gerais e Serro do Frio. Nomeado por carta régia de 7 de novembro de 1800 para o cargo, só assumiu a função efetivamente seis anos depois, quando uma nova carta régia, datada de 22 de dezembro de 1806, o nomeou para um outro cargo, o de intendente dos diamantes do Serro do Frio, do qual tomou posse no dia 27 de outubro do ano seguinte.

Câmara foi autor do alvará com força de lei de 13 de maio de 1803, que atualizou a regulamentação da atividade mineral na América portuguesa. Diversos pontos que aparecem no Alvará foram tratados por Câmara nos seus escritos elaborados em Lisboa, como também naqueles produzidos durante a sua viagem de especialização científica por vários países da Europa central e setentrional. Portanto, o alvará é um dos reflexos mais importantes da experiência européia de Câmara. O novo instrumento legal abolia a circulação do ouro em pó em todas as capitanias. Os "mineiros e faisqueiros" passavam a ter a obrigação de levar às Casas de Permuta todo o ouro que recolhessem, ou prestar informações nas mesmas, caso quisessem levar o metal à Casa da Moeda estabelecida na capitania de Minas Gerais. Esse item do Alvará já fora sugerido por Câmara no estudo que agora se publica. Na seguinte passagem, ele comenta a necessidade de tentar aplicar, em Portugal e no Brasil, o sistema de controle de circulação do ouro em pó utilizado na Transilvânia: 
Ao estabelecimento de uma semelhante administração entre nós, somente pelo que respeita ao ouro em pó ou nativo; pelo meio da qual Sua Majestade iria sucessivamente apoderarse da maior parte total do ouro extraído e a perceber realmente o quinto ou todo e qualquer imposto que Sua Majestade julgasse necessário estabelecer; se compõem diretamente a correr os países mineiros o ouro em pó como moeda donde a meu parecer vêm grandes danos, não só a Sua Majestade e a Sua Real Fazenda, mas a todos os seus estados em geral; sendo infelizmente verdade que nenhuma entre todas as moedas pode ser, tanto pela arte, como pela natureza mesma, mais falsa, assim como nenhuma se parte mais facilmente. Um dia eu pedirei à Sua Majestade liberdade de submeter ao seu Conselho reflexões mais desenvolvidas sobre esta importante matéria ...

Entre os itens constantes no Alvará, alguns foram devidamente executados, como o estabelecimento de casas de permuta para troca do ouro e compra dos diamantes, e o de casas de fundição para o ouro em pó. A circulação deste foi proibida, pois se acreditava ser esta a principal fonte de contrabando e 'descaminhos' do metal.

Câmara se manteve no cargo de intendente até 6 de abril de 1822, quando pediu demissão do mesmo, sendo a solicitação aceita pelo príncipe regente em 18 de maio do mesmo ano. Logo após se demitir do cargo, foi eleito, a 20 de maio de 1822, membro do Conselho de Procuradores Gerais das Províncias como representante de Minas Gerais, dando assim início à sua atuação na vida política do Brasil.

Câmara também atuou como deputado eleito pela província de Minas Gerais, no cerne da discussão sobre a criação da universidade no país, travada na Assembléia Constituinte de 1823. Apresentou, na sessão de 18 de outubro, uma emenda que previa a criação de uma escola mineralógica na província (Academia de Minas). O plano do deputado não foi atendido, sobretudo em virtude da dissolução da Constituinte.

\section{AGRADECIMENTO}

Agradeço ao professor doutor Manuel Serrano Pinto, da Secretaria Autónoma de Ciências Sociais, Jurídicas e Políticas da Universidade de Aveiro, a gentileza de ter-me informado a localização desse manuscrito de Câmara no Arquivo Nacional da Torre do Tombo, em Portugal.

\section{REFERÊNCIAS}

BENSAUDE-VINCENT, Bernardette.

Lavoisier: uma revolução científica. In: Serres,

Michel (Dir.). Elementos para uma história das

ciências. Lisboa: Terramar. p.239-268. 1996.

JANCSÓ, István; PIMENTA, João Paulo Garrido. Peças de um mosaico: apontamentos para o estudo da emergência da identidade nacional brasileira. In: Mota, Carlos Guilherme (Org.). Viagem incompleta, 1500-2000: a experiência brasileira. São Paulo: Senac. p.127-175. 2000.

PINTO, Manuel Serrano.

A memoir written in 1796 by Manoel Ferreira da Camara about mining in Transylvania. In: INHIGEO Meeting. Geological Resources and History. June $24^{\text {th }}$-July $1^{\text {st }} / 2001$. Proceedings of the $26^{\text {th }}$ INHIGEO Symposium. Aveiro: Centro de Estudos de História e Filosofia da Ciência e da Técnica/Universidade de Aveiro. p.363-372. 2003.

PINTO, Manuel Serrano.

A experiência européia de Manoel Ferreira da Câmara e seus reflexos no Brasil: algumas notas. In: Figueirôa, S.F. de M.; Lopes, M.M. (Org.). Geological sciences in Latin America: scientifics relations and exchanges. Campinas: Unicamp. p.245-264. 1994.

SIGAUD, José Francisco Xavier

Dr. Manoel Ferreira da Câmara de Bittancourt e Sá. Revista do Instituto Histórico e Geográfico Brasileiro, Rio de Janeiro, t.4, p.515-8. 1842. 


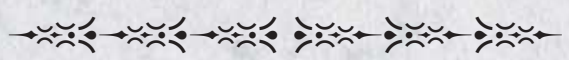

\title{
Nota sobre a extração das minas do Principado da Transilvânia escrita em Zalathna aos 5 de março de 1796, por Manuel Ferreira da Câmara
}

\author{
(Núcleo do Ministério dos Negócios Estrangeiros, caixa 526, \\ Arquivo Nacional da Torre do Tombo)
}

Em todos os Estados hereditários da Casa d'Áustria, como quase por toda a parte, o direito de extrair minas faz parte das regalias do Soberano, e se a cada um é permitido cuidá-las, e extraí-las, é porque o Príncipe não querendo ou não podendo extrair todas por sua conta, as cede a quem as pede. Esta cessão não é gratuita, pois que o possuidor de uma mina, recebendo-a, se obriga: $1^{\circ}$ a pagar o dízimo de todos os metais extraídos; $2^{\circ}$ a vender por preço fixo ao Soberano os seus metais, se os funde por própria conta; ou os minerais se o Soberano os funde; $3^{\circ}$ a sujeitar-se a uma administração estabelecida pelo Soberano que regule a extração; $4^{\circ}$ a ser julgado como mineiro por um foro particular, e a sujeitar-se às leis a este respeito.

De ordinários estas convenções sobre as companhias e as administrações, ou antes, entre os Soberanos e os proprietários das minas, são tácitas; às vezes, porém são expressas, e fazem parte da legislação montanhística.

Os Soberanos Austríacos, e todos os demais d'Alemanha, e pode ser d' Europa, se obrigam muitas vezes a prestar ajudas e socorros às companhias mineiras, socorros que nenhum lhes nega, se elas deles tem necessidade, ainda no caso de os não ter estipulado. Tais socorros diferentes ainda naqueles países que estão sujeitos ao mesmo Soberano, maiores neste que naquele, sucedem: $1^{\circ}$ a dar a madeira necessária para o espaldamento das minas; $2^{\circ}$ a vender as lenhas necessárias às fundições por um módico preço; $3^{\circ}$ a não receber o dízimo das minas que dão perda; $4^{\circ}$ a pagar mais caros os metais extraídos de uma mina que se [ilegível] em grandes despesas; $5^{\circ}$ a fornecer aos mineiros, que não podem, nem devem ser ao mesmo tempo agricultores, os fretes que lhes são necessários por um baixo preço tanto no tempo de abundância como no de carestia; $6^{\circ}$ a isentar os mineiros de certas imposições penais a que devam estar sujeitos; $7^{\circ}$ a conceder-lhes privilégios reais, como devam pagar sisa pelos objetos necessários à extração das minas; $8^{\circ}$ a abrir galerias de esgoto, e trabalhos úteis a um grande distrito de minas, sujeitando os mesmos a pagar por isso certa contribuição, e outros muitos socorros de que seria longo fazer enumeração.

Por toda a parte nos Estados d'Áustria, em que até na Alemanha, cada mina é dividida em 128 ações, e considerada como uma companhia pela administração; ainda no caso de todas as ações estarem no poder de um só. Quanto ao modo de adquirir a propriedade 
delas, é o mesmo por toda a parte dá-se sempre ao primeiro que se apresenta uma determinada data; conquanto nela se senão descobrem minerais a seriam as dela [ilegível] no protocolo do Conselho das Minas: logo, porém que a única descoberta merece a atenção da administração; ou porque dá, ou porque promete; esta passa, para assim o dizer, das mãos e do poder do proprietário, ao poder da administração, ficando a sua desobrigado, da condução dos trabalhos, e percebendo a utilidade, se acha ou contribuindo com as despesas, se a mina as erige. Surpreende sempre que nenhum proprietário pode ter todos os conhecimentos necessários para extrair com regularidade, e com utilidade ao mesmo tempo, tendo a experiência mostrado que nenhum, atrás de um proveito momentâneo, deixa de destruir e roubar as minas que possui, se delas tem a administração; o que nunca acontece sem grande perda sua e do Estado.

A administração tem uma conta muito exata por partidas dobradas com cada mina, não só por saber-se o que todas produzem, e o que dependem, como uma parte essencial das finanças dos países mineiros; mais para saber se o estudo de cada uma, e se esta ou aquela está no caso de ser socorrida ou não.

Segundo o sistema que atualmente tem recebido na Alemanha, o que em todas as nações aprenderam sempre em matéria de Economia Montanhística pública, ou privada, os fundos empregados na extração devem ser vendidos ao proprietário, antes que a mina se considere em estado de proveito, donde sim que somente aqueles que compram ações de minas em bom estado devem contar com o interesse do capital que nelas puseram, aqueles, porém que de princípio as obtiveram, e são tão [ilegível] com o proveito de um fundo que se não possui eixo. Donde são os diferentes Estados com que estão: $1^{\circ} \mathrm{o}$ de perda para os acionistas quando elas exigem deles avanços para se edificar; $2^{\circ}$ se a mina produz tanto quanto lhe é necessário para se edificar a sua própria custa; $3^{\circ}$ se ela tem exigido avanço da parte dos acionistas vindo depois a melhor estada, e tendo-se feito um pequeno fundo que os assegure de não tornar a despender com ela por algum tempo, lhes começa a pagar ou indenizar a soma com elas gasta; $4^{\circ}$ subestimo se a mina, depois de ser indenizado aos proprietários as despesas que fizeram continua a dar proveito, e se divide o seu produto por cada acionista, o que todavia não deve acontecer sem que ela tenha aumentada a sua caixa ou reserva.

Cada um destes estados é, como acontece quase por toda a parte, diferentemente considerado por toda a sábia, e justa administração. Se a mina se acha no primeiro estado, em vez de se exigir dela ou dos proprietários o dízimo se lhe prestam socorros, e mesmo se lhe fazem avanços e empréstimos de sua caixa destinada a esse fim, se esta promete pagálos. Se está no segundo estado o Soberano recebe em vez do dízimo somente o vigésimo. Se no terceiro recebe o Soberano os seus direitos. Se no quarto enfim ajuntam-se quatro ações às 128; ações livres, que servirão logo que a mina da perda, as que pertencem ao Soberano que delas faz ouro que bem lhe parece acrescentando-lhe este proveito aos demais que lhe resultam da extração.

Cada grande país, ou distrito de minas, é administrado por um Conselho entretido pelo Soberano; Conselho composto de ordinário por um intendente geral ou particular, de Conselheiros ou assessores, de jurisconsultos ao mesmo tempo instruídos na arte de minerar, de um diretor dos trabalhos montanhísticos, de um outro dos de fundição, como de oficiais subalternos. Às vezes a administração dos bosques se acha unida ao conselho das minas para 
muito nos sítios onde eles são destinados a este fim. O Diretor dos trabalhos montanhísticos, considerado no grande conselho como um assessor, preside a sua junta inferior composta dos geômetras subterrâneos dos muitos mineiros, dos jurados ou louvados das minas, assim como de outros inspetores subalternos. O Diretor das fundições tem em alguns lugares um corpo semelhante, composto de um vice-diretor, dois ensaiadores, muitos fundidores e dois oficiais de um renque inferior. De ordinário no centro das províncias mineiras se estabelece a direção ou conselho das minas, para que possa facilmente viajar sobre todos os distritos vizinhos, nos quais já as fez ali empregados [ilegível] junta subordinada às primeiras.

Todos os corpos de minas dos Estados austríacos são, como em Saxônia e no Distrito de Hannover, independentes de qualquer jurisdição civil ou política, que não provenha do Grande Conselho de Finanças, que tem a seu cargo a inspeção das minas, assim não havendo conflito de jurisdição, nenhum obstáculo desta natureza ou prepotência, embaraça o curso dos negócios montanhísticos. Em alguns lugares o Conselho [ilegível] nos distritos mineiros à jurisdição civil e criminal, em outras a civil, e parte da criminal.

A experiência tendo mostrado que nenhum proprietário pode fundir com proveito os minerais de uma só mina; os Soberanos dos países mineiros, para tirar dos minerais o maior partido possível, os fundem de ordinário por sua conta e risco. Eram só da faculdade de fundir juntos, os que assim convém fundir resulta grande proveito ao Soberano e ao Estado igualmente, mas simplificasse consideravelmente a percepção dos Direitos Reais. Cada mineiro ou proprietário envia às Fundições Imperiais, os minerais extraídos das suas minas, e segundo o seu conteúdo, mostrado por três diferentes ensaios, se lhe pagar em moeda o valor, abatendo-se as despesas de fundição, assim como toda a sorte de direitos que se hajam de perceber dos proprietários das minas donde lhes [ilegível].

A parte do colégio, ou Conselho de Finanças, que a seu cargo tem na administração e inspeção das minas é composta de Conselheiros que não só aprenderam a arte das minas, e igualmente a economia montanhística, mas que foram intendentes e chefes nos distritos mineiros; e dão-se aquele, que conhecem melhor sua província, os negócios a esta pertencentes, para os referir; donde vem que cada um destes relatórios no Conselho de Finanças, pode facilmente apontar os erros das administrações subalternas, que uma vez conhecidas, procura-se logo dar-lhes remédio enviando aos ditos distritos comissários munidos de instruções, e poderes necessários a este fim.

São estes os fundamentos sobre que se fundaram as administrações mineiras, que me são conhecidas; são estes os meios que tenho visto fazer uso por toda a parte para as minas regular, e simplificar a extração das minas; atualmente eu vou me ocupar da administração da Transilvânia em parte que por isso mesmo que são é a melhor dos Estados Austríacos merece ser conhecida, e que todavia não deixa de ser digna de ser imitada naquela parte que é ou pode ser comum com o estado das coisas entre nós.

A Transilvânia é entre todos os domínios hereditários da casa d’Áustria aquele, que pela divisão das nações que a habitam, pela multiplicação das religiões que professam, pelos privilégios de que gozam, assim como pela distância da capital ou sede do Soberano, para se juntar menos a uniformidade de leis e de costumes que regem todos os outros, contribuindo muito além disto muito à vizinhança da Hungria, de cuja formação e sistema de governo participa muito. 
Três nações diferentes professando quatro diferentes religiões, que não são toleradas mas estabelecidas pelas leis, e gramáticas, dividem com o Imperador como Príncipe do país o direito de legislar; reunindo-se em Estados de três em três anos. A nação Cicula antiga libertadora destas regiões, católica, a Lapônia luterânica imigrada nos tempos de perseguição; a Hungria Calvária e Luterana; enfim, diferentes indivíduos das três nações referidas, e particularmente húngaros, professando a religião Ariana, são as que gozam de uma parte do poder do Soberano, e de privilégios inauditos, que o desejo de possuir este país escapado da proteção turca, e a necessidade de o povoar obrigou a conceder ainda a homens que não são capturados.

Além dos poucos alemães que aqui se acham reunidos à Nação Saxônia, ou empregados nos diferentes ramos da administração do [ilegível], a Nação Valaca, professando as duas religiões gregas. Conhecidas a unida e a cismática, posto seja apenas tolerada, faz quiçá dois terços da povoação do país, e sem elas não viria [ilegível] ao Imperador nem aos proprietários dos fundos, metade dos rendimentos que tiram a este Principado.

Armênios, Macedônios, Ciganos, Búlgaros, Dácios, Judeus, e enfim Eslavos, fazem ainda uma parte da povoação da Transilvânia, e se excetuarmos os Búlgaros e Lapônios todas as nações referidas; só particularmente a Valaca, são pouco fortunadas; e aderidas aos terrenos que cultivam a benefício de outrem passam uma vida miserável, e se avizinham ainda muito do estado de barbaridade.

No entanto, a nação Valaca é a que se ocupa mais da extração das minas, e prefere habitar as montanhas, onde por isso mesmo que se dão a um gênero de indústria privilegiado são, para assim dizer, menos escravas dos proprietários das planícies destinadas à agricultura.

Isto posto não será difícil de acreditar, se eu disser, que a aceitação da Transilvânia, fazendo-se pela maior parte por proprietários pouco possibilitados, não seja nem muito proveitosa a eles mesmos, nem ao Soberano; se todavia ela é de grande consequência para o estado pelo seu produto anual, e se este sofre alguma perda real, é seguramente a da destruição das minas que tratadas de outra maneira, e como quisera o Imperador que elas fossem tratadas; prometeriam a posteridade os mesmos subsídios de que os habitantes atuais gozam.

Pelo Decreto do Imperador Lespotão, o primeiro que se apossou deste principado, e pelos consentimentos dos Estados, que preferiram ser seus vassalos a ser feudatários do turco, a extração das minas é livre a qualquer que dela se queira ocupar, contanto que pague ao Soberano o dízimo do seu produto. Pelo mesmo decreto ou antes pelos antigos a ele adidos, chamados novos; a liberdade de extrair o ferro em metais vis assim perfeitos, não tem limite, e deles não é devido ao soberano o mesmo dízimo.

Para que melhor se entendam as diferentes partes da administração montanhística da administração da Transilvânia, eu farei-me ocupar em fazer menção dos diferentes metais que aqui se extraem e de como cada um é diferentemente considerado pelo Soberano.

O ouro nativo, tal qual se acha entre nós, e o mineralizado, que desconhecemos se o possuímos, é o objeto principal, tanto da extração como da administração imperial. Vem depois a prata que aqui se acha sempre mineralizada com mais ou menos ouro, e que se obtém com ela pelas [ilegível] ordinárias, ou pela fundição, em vez que o ouro nativo se 
apura pela lavagem e pela amalgamação. $\mathrm{O}$ cobre não faz um artigo de grande consideração na Transilvânia, posto que o Imperador, pela boa saída que dá a toda que extrai do Bonato e da Hungria, punha em movimento todos os meios de que pode dispor para aumentar este produto, de que não recebe mais da décima quarta parte, ainda no caso de haver proveito da parte dos proprietários das minas que os dão.

Ainda que o ferro seja uma propriedade do senhor do fundo em que lhe se acha, de que não é obrigado a pagar direito ao Soberano, este metal faz um artigo considerável das rendas do Imperador, por ser ele o proprietário da principal entre as muitas poucas fábricas de ferro, que existem em toda a Transilvânia, e se a natureza não foi aqui mesquinha espalhando o ouro, parece tê-lo sido distribuindo mal o ferro; assim este metal, sem o qual toda a extração [ilegível] é caro na Transilvânia. Eu desimbro [sic] na liberdade concedida a todos de extrair o ferro sem encarrego de dízimo, que de tempo imemorial, e que os tesouros entranhados na terra, assim como os que ela patenteia a superfície, senão podem a isso evitar sem este precioso metal.

Chumbo falta quase inteiramente neste país, e o que é necessário para por meio dele separar o ouro e prata dos minerais que as contém pela fundição; vem quase todo de Bleyberg, na Caríntia, custando somente este artigo ao Imperador grandes somas pela dificuldade de transporte. Decanto aos metais chamados cris ou imperfeitos, ainda que entre eles o antimônio seja frequente na Transilvânia, irão se faz [sic], protestando-se ou não pagariam despesas de extração, e de transporte; assim a liberdade de os extrair, sem deles pagar dízimo, não é de alguma consequência para o Estado, e para o Imperador.

Vejamos atualmente que meios se descobriram aqui para que as [ilegível] do Imperador, ou d'administração, venha tanto o ouro nativo colhido por um grande número de trabalhadores, cada um dos quais não apura de ordinário mais do que lhe é absolutamente necessário para viver, de cujas pequenas parcelas se ajuntam todavia ano comum, sem extravio, de cinco a seis quintais de ouro em pó, que atentamente a extração deste metal nativo na Transilvânia mantendo a do mineralizado a outro tanto.

Eu suplico da parte de Sua Majestade e de seu Conselho uma ação particular sobre este ramo da administração da Transilvânia, por estar persuadido que da sua introdução entre nós viria, tanto a Real Fazenda, como a seus vassalos, e a seus Estados em geral de grande benefício. Eu sei que o extravio do ouro no Brasil mereceu ultimamente a consideração de Sua Majestade e que vem de publicar um Alvará pelo qual se espera evitar um tão forte contrabando; mas eu ignoro inteiramente as disposições desta lei.

O ouro nativo se acha aqui, como entre nós, nos atirar dos veios e suas margens, ou lavradas de cascalho transportadas em outro tempo das montanhas vizinhas pelas águas, ou no interior da terra em veios, bancos, ou camadas, disseminada em rochas que não são cortadas a parte das mesmas. Uma observação que merece, tanto a atenção do Geognosta, ou daquele que se ocupa da ciência montanhística; assim como do homem de Estado e financeiro é que ambas estas formações douro são aqui, como entre nós, ouro de muito diferente quilate. $\mathrm{O}$ de transporte contém mais matéria pura em uma dada quantidade, que o extraído das montanhas, e dos leitos acima lembrados; assim tudo o que se pode obter separado, em porção considerável, se paga pela administração por um preço muito maior, que o quê se sai das minas. 
O ouro de lavagem do distrito d'Olapían frio de 22 a 23 quilates é o único diferentemente considerado no pagamento. O Imperador dá por cada pirota, que com pouca diferença equivaleria à nossa oitava, quatro floríns e quatorze [ilegível], isto é, pouco mais ou menos de 17 [ilegível], em ser que pelo ouro nativo puro vindo das minas em pó ou fundido em barra; de ordinário fino de 16 a 17 quilates se paga muito menos, dois florins e quarenta e quatro Krutzers pelo [ilegível], e dois florins são oitenta e nove Krutzers pelo amalgamado, ou fundido. Os preços estes que se avizinham muito do que a lei do ouro em pó, e não quintado, entre nós, considerado do mesmo modo o mais fino que o mais baixo, assim como o puro e o impuro; bem entendido que falando de impurezas, eu entendo aquelas matérias que acompanham sempre o ouro em pó que senão podem separar pela lavagem sem grande perda.

Estes preços foram estabelecidos pelo Soberano de acordo com os Estados, e posto que o Imperador substrata na compra o dízimo; que lhe é devido, e as despesas de moedagem, e ganhe ainda, são raríssimos e inauditos os exemplos de um proprietário prefira, a que lhe é proibido, vender a outrem assim ouro, que a administração imperial; e pelo que respeita ao ouro fino de lavagem, de que falei a pouco, ninguém lhe daria mais por ele que o Imperador, e dignamente entre todos os mais de evitar o extravio de materiais preciosos; o melhor é a de calcular e arrumar as coisas de maneira que o Soberano, ganhando todavia muito notado, venha agravar tão pouco em uma pequena parcela, que esse ganho não estimula a ambição de uma parte, para quem o ganho não estaria em proporção com o risco.

Para facilitar a compra ou troca do ouro, embaraçar ao mesmo tempo o contrabando, o Imperador estabeleceu em todos os distritos, onde há minas ou lavagem de ouro, uma pequena junta composta de dois ou mais oficiais, se a necessidade exige, que se ocupa somente em receber o ouro que em dias determinados [ilegível] os que a possuem. Eu fui visitar estes estabelecimentos, para estudar como se procede a esta compra, instruindo-me ao mesmo tempo, das precauções que se tomam para que o trono imperial não perca, seja por falsificações dos que vendem, seja por [ilegível] dos que compram. Estas são compostas de um recebedor, de um escrevente que serve ao mesmo tempo de fiscal ou contratante; às vezes [ilegível] dos que vendem é grande há mais dois oficiais: um pagador e um contador. O que recebe o ouro não pergunta aquele que atrás donde [ilegível], nem como; antes porém deu para examinar, e ver se até pode ser roubada como ouro em pó. Se o ouro não tem senão ferro, separa por meio da magnetita, e ao escrevente então nota o nome do que o trouxe e a quantidade; o pagador consulta uma tábua onde todos os preços se acham calculados e lançando mão do dinheiro, que lhe repassa de conta ou faz os pagamentos. Se o ouro não é oficialmente puro passa a ser recebido como ouro em pó, o recebedor torna a dar ao passador com medalguas grossas de mercúrio até algumas onças; segundo a quantidade de ouro, para que os amalgame, operação por meio da qual a maior parte das misturas estrangeiras que costumam acompanhar o ouro se separam. Dá-se além do mercúrio a cada um, cujo ouro deve ser amalgamado, uma almofar de ferro; feita a amálgama, se a porá em um forno semelhante à de ensaio com mercúrio combinado com o ouro. Um o cal preside ainda a esta operação para que se lhe dê o grau de calor, e tempo necessário para que não fique mercúrio [ilegível] d'amálgama, que se pagara como ouro. O rendador divide a [ilegível] em duas metades para ver se houve falsificação, no caso de a suspeitar o ouro e falo ensaiar. 
Se qualquer é convencido de ter falsificado uma parcela d'ouro; e nisso tomam sem sentido os oficiais que são responsáveis por toda a administração considerável, examinar desrespeitosamente se lhe pode pagar a condenação estabelecida pela lei, que montas além da perda do ouro a 200 florins; se ao contrário, paga a com a peste, se lhe fazem dar de 50 a 100 pauladas em lugar onde os ossos não correm risco de ser molestados.

Os valacos, posto que pouco aviltados, são suficientemente hábeis na arte de falsificar o ouro; e como o cobre dilatam, de que se faz uso entre nós, não se amalgamam facilmente, servem-se da prata, mas guardam se bem se lhe ajuntar mais do que é necessário, para que o ouro venda a 16 quilates e meio; até lá podem ligar impunemente por ser o quilate do ouro mais baixo que a que se extrai das minas; se porém a liga é em maior quantidade, para evitarem a condenação ou pena, devem provar perante o juízo das minas, que na mina em que trabalham, ganhem ouro nativo de quilate.

Tais contratações provêm de se pagar pelo mesmo preço, tanto o ouro provindo de sua mina os de lhe se achar de um alto quilate, como o que vem de outra, que o dá abaixo. $\mathrm{O}$ Imperador quisera bem evitar esta origem de falsificação, difícil de conhecer, logo que senão recorre ao ensaio; mas nem é possível pagar, segundo a constituída em matéria pura, parcelas às vezes tão diminutas, que não excedesse o valor de meio tostão, [ilegível] do que vale o material ensaiado. É, porém, digno de admiração que recebendo-se tão pequenas parcelas, se possam ajuntar caso cá viesse uma [ilegível], em uma só junta, oitenta marcos de ouro, a metade do qual foi amalgamado no mesmo dia.

Quanto aos meios de evitar enganos da parte dos empregados na compra do ouro, cada um dos recebedores tem como fica dito um contraste ou fiscal; o que sem um visto e pacto de todo o ouro recebido e do dinheiro por ele dados. O primeiro recebedor ou caixeiro-mor dos fundos destinados à compra do ouro faz entregar todos os meses o dinheiro necessário às diferentes juntas, e recebe a lei de lhes enviar o dinheiro para o mês futuro o ouro comprado com o dinheiro precedente. Por este modo sabe-se com facilidade a quantidade que montam as despesas de cada junta de mês em mês; o dinheiro que lhes sobra; o que tudo comportado com a quantidade de ouro recebida faz ver se houve ou não malvenação de um fundo, que nunca é grande.

No registro da compra do ouro se escreve o nome daquele que o trás e a quantidade, não só para que saiba quem entregou mais, ou tanto quanto é necessário para gozar do privilégio de mineiro, mas para que se tenha um dado demais, no caso de ser mister proceder a um balanço grande. Um mineiro ou lavador de ouro, que entrega certa porém anualmente, tá livre de dar cavalos à pasta militar, de trabalhar nas obras públicas, de ser recrutado, não paga uma capitação tão grande como outro qualquer, que se ocupa de um gênero de indústria não privilegiado. Os ciganos, sorte de gente vagabunda que como disse faz uma pequena parte da povoação deste país, são os que se ocupam em lavar ouro nos rios Maros e nos Aranÿos, comparados pelos habitantes do nosso Tejo, por trazer ouro misturado com as suas areias. Logo que um cigano entrega anualmente pouco menos de uma onça de ouro, goza dos privilégios acima, se considerado como um mineiro ou lavador de ouro, e não paga mais de um florins de capitação.

Ao estabelecimento de uma semelhante administração entre nós, somente pelo que respeita ao ouro em pó ou nativo; pelo meio da qual Sua Majestade iria sucessivamente 
apoderar-se da maior parte total do ouro extraído e a perceber realmente o quinto ou todo e qualquer imposto que Sua Majestade julgasse necessário estabelecer; se compõem diretamente a correr os países mineiros o ouro em pó como moeda donde a meu parecer vêm grandes danos, não só a Sua Majestade e a Sua Real Fazenda, mas a todos os seus estados em geral; sendo infelizmente verdade que nenhuma entre todas as moedas pode ser, tanto pela arte, como pela natureza mesma, mais falsa, assim como nenhuma se parte mais facilmente. Um dia eu pedirei à Sua Majestade liberdade de submeter ao seu Conselho reflexões mais desenvolvidas sobre esta importante matéria e fazendo por ora convenha [ilegível] eu vou tratar daquela parte da administração da Transilvânia que se ocupa, tanto quanto é compatível com as leis e costumes recebidos, em regular a extração e fundição dos minerais, fazendo ao mesmo tempo ver como são diferentemente considerados pelo Soberano o ouro, a prata, e outros metais que provêm desses minerais fundidos para contar sua parte da administração que ainda pode ser adotada entre nós; se Sua Majestade não achar conveniente estabelecer outra melhor, acabando por uma vez com os obstáculos, que lá como aqui, se apóiem a boa ordem da extração; obstáculos para os vencimentos dos quais será necessário da parte de nosso Governo menos prudência, constância e energia ao Imperador; expostas as leis fundamentais deste principado, e a diversidade de interesse das diferentes nações privilegiadas que o habitam.

Como pelas leis e costumes do país a extração das minas é livre a que consegue a faculdade de extrair uma certa data; o Imperador não podendo aqui submeter os proprietários a uma certa ordem e regularidade; de que toda a alta extração não se pode dispensar, tomou o partido: de estabelecer uma administração, e oficinas de minas a quem paga para servir; e guiar aqueles proprietários que voluntariamente se querem servir dela. Quanto ao direito de fundir, e dispor como bem lhe parece dos minerais ganhados de todas as minas; não foi difícil ao Soberano ganhar esta propriedade pela impossibilidade em que cada um estava de construir sua fundição, de pagar os empregados a ela necessários e de vir a fundir com proveito.

A administração geral da Transilvânia estabelecida atualmente em Zalathna, é com pouca diferença organizada da mesma sorte, que as demais dos Estados do Imperador, pelo que respeita as partes de que é composta. Ela é presidida pelo tesoureiro ou ministro das finanças deste principado que sendo ao mesmo tempo conselheiro reside a [ilegível]. Um vil presidente também conselheiro de governo do país faz as suas vezes quando ausente: um Diretor dos Trabalhos Montanhísticos, um outro dos de fundição, um quinto das máquinas que servem a pilhar e lavar os minerais; um provedor de mantimentos e objetos necessários à extração; um guarda-livros e um recebedor mor de ouro em pó, que é ao mesmo tempo caixeiro-mór; todos os assessores do presidente, um secretário e diferentes atuários são os ofícios de que é composto o conselho de administração. Com a execução das leis e privilégios montanhísticos, e os processos dos mineiros entre estes formaram a tempo a administração, que se deve somente ocupar na regularidade dos trabalhos, e cuidar na arrecadação dos direitos imperiais; aquela parte da administração forma um Conselho a parte, composto de um juiz conservador, de quatro assessores tirados, segundo as leis das quatro nações privilegiadas, de dois secretários, de um visitador ou um atuário, e de três chancelistas. O provisorado, a caixa, a manutenção dos livros, a chancelaria 
fazem ainda na administração pequenas decisões separadas, cada uma das que têm diferentes [ilegível]. Além destes o Imperador paga aos ensaiadores das minas, e das fundições, aos geômetras subterrâneos, aos subdiretores das fundições, enfim aos diretores mais empregados que residem nas minas que se sujeitaram à administração ou que pertenciam ao Soberano.

Para chamar a administração das minas da Transilvânia e convidar os proprietários a sujeitarem-se acha, o Imperador, consultando antes a utilidade pública que as [ilegível]; paga mais caros os minerais extraídos das minas dirigidas pelos seus o [ilegível] e que prestando duas contas ao Conselho das minas. Avança aos proprietários se lhes têm necessidade, fundos das casas das minas sem interesse; perdoa-lhes uma parte do dízimo; donde vem que pouco a pouco as minas vão ter às mãos da administração para poderem gozar destas vantagens. Uma grande partes delas ficam todavia por muito tempo na impossibilidade de gozar dos benefícios referidos, porque extraídas por valacos, nação pobre e pouco instruída na arte de minerar, não podendo saber, porque apenas os seus padres sabem ler, se da mina em que trabalham davam perda ou proveito nem querendo o que outrem o saiba não é possível por nenhum dos meios até que lembrados, obrigados a extrair com regularidades. De outra parte uma nação pouco necessitada pelo hábito de se privar de tudo, cuja nutrição custa menos que a dos outros povos, jejuando por costume e por religião dois terços do ano, vestindo-se do pano o mais grosseiro, pode dificilmente ser obrigado pela necessidade [ilegível] sobre a extração, ou servindo-se por meios lucrativos a sujeitar-se a uma certa ordem de coisas. Assim quando é permitido entrar nas suas minas, o que acontece somente quando são pobres particularmente a [ilegível], crê-se entrar em sua cocheira, onde cada animal faz o seu curral segundo a sua fantasia ou facilidade que acha em a digerir deste ou daquele lado.

Por toda parte os que se ocupam da extração das minas se reúnem em um corpo de sociedade composto de tantas outras quantas são as minas que se acham em extração cada associado contribui com as despesas necessárias à extração da mina, o que não acontece assim entre os valacos. Se dois ou mais se reúnem para extrair uma mina, um dá a luz por alguns dias, outro a pólvora, outros um instrumento de ferro dos que se faz ouro nas minas, e dividem enfim os minerais ganhados por tão fracos meios. Cada um tem em propriedade, ou arrenda, um pequeno engenho de pilões onde pisa os minerais que ganhou: destes obtém ouro em pó, e minerais, contendo o ouro e prata. O ouro em pó é vendido logo à administração pelos preços acima ditos; os minerais vão ter à fundição onde logo que estes trazem de três a quatro quintais do conteúdo necessário para que se perda pouco; as despesas de fundição são recebidas pela administração que não pode deixar de os mandar ensacam para saber quanto constem, e o mais das vezes perde a despesa do ensaco pela pobreza dos minerais.

Mil e duzentos engenhos de pilões destinados a pisar e lavar o ouro, se encontram em toda a Transilvânia, e eu duvido que em todo o Brasil se contem duzentos destinados a esse fim, fazendo de ordinário entre nós os braços do homem, o que aqui faz suas máquinas que construídas à maneira dos valacos não custa mais de 4 ádris.

Segundo as novas ordenações artigo trinta e quatro parágrafo quarto onde se trata das minas e dos metais, que rigorosamente falando, é um esqueleto das leis montanhísticas estabelecidas na Alemanha se determina, que sendo as vias tão pobres (fracas) que não sopram pagar o dito direito (o quinto a eles) nos requeiram para prover como for necessário. 
Deste parágrafo da ordenação se vê que em outro tempo se faria também entre nós (a riqueza e estado das minas em extração, o que não acontece hoje em dia; e se busco a versão de ter caído em desuso esta lei; acho-a na falsa de uma tal administração qual êxito em outro tempo entre nós, e que só pode colher pelo artigo primeiro, segundo e quinto do mesmo título da ordenação; assim como na possibilidade de poder-se saber quais entre as minas estão no caso de gozar de um tão grande benefício; e não sabendo de ordinário no Brasil o proprietário que proveito ou perda lhe vem das suas minas ou catas, não é de admirar que o Soberano o ignore. Voltemos à administração da Transilvânia).

Os minerais extraídos de todas as minas são, como já dito, entregues às fundições para serem fundidos por conta do Imperador; ele paga então a cada proprietário o valor intrínseco dos seus minerais em moeda corrente, isto é, 24 florins por marco de prata fino, e 366 florins por cada marco de ouro de 24 quilates, abatendo-se ao proprietário o dízimo se as minas donde vem os minerais os deve pagar; assim como as despesas de fundição abatemse-lhe mais cinco por cento de perda ao fogo, e as despesas de moedágio. Para o pagamento dos minerais há tarefas calculadas para facilitar os pagamentos, e tarifas que se estabeleceram segundo a menor despesa feita com esta classe de minerais e maior com aquela outra: há porém uma classe pobre que se sabe se se coube separar toda a [ilegível] para que é necessário fazer para os aproveitar; e posto que o Imperador para conceder tantos favores aos mineiros, pelo que respeita as despesas de fundições, manda [ilegível] os minerais a sua custa, despesa que nos minerais de ouro monta a somas consideráveis, os Estados sempre têm de que se queiram, motivos para pedir mais altos pagamentos pelos minerais.

Os proprietários de minas que se submetem à administração ou lhe comunicam as suas contas, gozam do benefício de se lhe pagar o ouro nativo que obtêm dessas minas para lavagem, como se paga o ouro convertido nos minerais, isto é, a razão do contido em prata pura, em que aos que extraem bem como lhes parecer as dão contas a ninguém do que ganham, e dos que perdem; se lhes paga o ouro nativo em pó segundo os preços fixados na compra do ouro, isto é, a verão de 2 florins 4 Krutzers pelo ouro em pó e 2 florins 59 Krutzers pelo amalgamado.

O todo o ouro e a prata que se obtém das minas da Transilvânia é enviado à Casa da Moeda de Cartaburgia, onde são cunhados. O fabrico da moeda, e das drogas materiais, que são necessários a esse fim, faz em todos os Estados do Imperador e em geral na Alemanha, parte da administração das minas ou está com ela incorporada. Segundo a conta corrente da Casa da Moeda de Luxemburgo, ela pagava caixa d'administração das minas da Transilvânia; segundo o valor intrínseco no ano próprio passado $1^{\circ}$ pelo ouro obtido pela fundição dos minerais 362202 florins; $2^{\circ}$ pela prata ligada com ele colhida pelo mesmo meio 72472 florins; $3^{\circ}$ pelo ouro em pó comprado dos mineiros 347469 florins; $4^{\circ}$ pela prata naturalmente ligada com ele 10023 florins. Estes metais custaram ao Imperador $1^{\circ}$ os minerais que produziram as suas primeiras somas, 355\&646 florins, no que houve um ganho de 89028 florins; $2^{\circ}$ o ouro em pó e a prata com ele ligada fazendo as duas parcelas; $3^{\circ}$ e $4^{\circ}$ custaram apenas ao Imperador 2318371 florins em que houve ganhado de $126 \& 121$ florins.

Os dízimos das minas de ouro, prata e cobre não produziu naquele ano mais de 7548 florins, e todos os benefícios e ajudas, que o Imperador prestou às minas que se sujeitaram à administração não montaram a mais de 3549 florins. 
Se o Imperador não tiver outro benefício do produto das minas que o dízimo; se o perceber rigorosamente, não viria a ganhar naquele ano / dado o ouro que as minas produziram em tanto sem os socorros que lhe são postas, que com eles, do que se pode duvidar / mais de $71 \& 216$ florins; se em vez do dízimo em vez tivesse o quinto o ganho não passaria de $142 \& 432$ florins: ora nós temos de benefício nas parcelas $1^{\circ}$ e $2^{\circ}, 89.28$ florins, nas parcelas $3^{\circ}$ e $4^{\circ} 126121$ florins somando só 5149 florins. Parece logo que o Imperador pelos meios até aqui lembrados vem a tirar maior proveito das minas que tiraria se receber o quinto do ouro, e deixar com Sua Majestade a extração a arbítrio de cada um.

Toda a conta feita, não sofre questão, que os proprietários das minas são sempre os que pagam todo o proveito que o Imperador delas tira, mas não é menos verdade que cada um paga em proporção do que ganha, e que aqueles que não podem contribuir, pelos termos que se lhes prestam, seguem mais dia menos dia em estado de o poder fazer. Note-se, porém excetuado a compra do ouro em pó, onde o ganho é mais em relação das despesas; de nenhum país mineiro tira o Imperador menos proveito que da Transilvânia.

As despesas da administração, as de fundição absorvem grande parte do benefício que o Imperador tira destas minas, mas a despeito de tudo é indubitável que da extração das minas tirem grande proveito, podendo ele fazer valer os seus bosques, de que se não viria nenhum proveito, senão tivesse menos que fundir.

Quanto aos benefícios que delas nutram a todos os seus estados eles são insalutáveis. Na Transilvânia assim como na Hungria não há tábuas e as dos outros Estados hereditários da Casa d'Áustria lhe fornecem tudo de que os habitantes têm necessidade em troca do ouro; o Imperador não as defende, mas protege quanto pode esta indeferência para tudo que não lhe extrai metais, e principalmente prata, ouro e cobre. Além disto, um país cercado, como este por outros como ele, fertilíssimos, tais são o Bonato, e a Hungria pode contar pouco com o ganho que lhe vem da agricultura, e não acha outra saída aos frutos que produz; senão naqueles que se ocupam de um gênero de indústria estável.

O imperador, considerado como particular, tem também parte na extração de algumas minas, sentam grande em umas e perde em outras: por confundir sempre o interesse dos particulares com o do Soberano ou com o público, por preferir este àquele, ele dirige sempre os seus trabalhos a benefícios dos outros; e neste caso não é de admirar, que segundo as contas do ano passado que diversificam muito das dos anos precedentes, pelo que respeita ao proveito o Imperador ou extrai de suas próprias minas $45 \& 526$ florins e despender com elas 75\&964 florins.

Da guerra atual também veio às minas grande dano, e $1^{\circ}$ abandonaram-se os trabalhos de que viria grande bem a extração em geral, $2^{\circ}$ forçaram-se outros, e a reserva que devia sustentar aquelas minas em proveito por muito tempo, se extraíram em pouco tempo, sem dar atenção ao futuro: os mesmos particulares foram forçados a fazerem esta sorte de trabalho a que os Alemães chamam nos termos d'arte trabalho de roubo para poderem cortar as contribuições.

O Imperador considerado ainda como particular tira, como já dito, um grande proveito do fabrico do ferro e aço benefícios desigual por depender d'abundância d'água, e de serem os anos mais ou menos chuvosos, e que é somente grande por poupar por meio dele as despesas que (ilegível) fazendo ver demais longe do ferro necessário a extração das 
minas; o lucro que daí lhe vem vai de 25 a 30 mil florins anualmente. Se o Imperador, porém vendesse aos proprietários das minas o ferro e o aço pelo mesmo preço, pouco que um pelos outros, não excede 7 florins por quintal, o lugar que dali tiraria seria de certo maior; mas ainda neste artigo essencial lhe os socorre.

Pelo que respeita ao benefício da renda do pouco cobre que se extrai na Transilvânia; ele não excede ano comissão a seis mil florins, a receita do ano passado neste pequeno artigo montou a 5137 florins. Na venda do cobre, um dos maiores artigos de exportação dos Estados do Imperador, ele ganha sempre [ilegível] a metade do que esta metade lhe custa por não o pagar aos proprietários ou companhias por mais de 32 florins por quinto e vende-lo muitas vezes por sessenta e mesmo a vez de cem florins só dele se faz o latão. O Imperador recebe por todo o grande o dízimo dos minerais de cobre, a que se não recebe mais da $14^{\mathrm{a}}$ parte.

Eu não quero por último deixar de falar de um processo que ocupa atualmente a administração e câmara de finanças. Há alguns anos a esta parte que a fundição de Zalathna passava pela melhor d'Europa; por fundir com proveito minerais de um muito tênue conteúdo esta fama me deu de vir passar aqui uma parte do inverno para estudar o seu processo que todavia não difere do adaptado por toda a parte. No tempo em que se introduziu a amalgamação dos minerais d'Europa, adoção que começando nos Estados do Imperador, é mister hoje ir lá estudar na Saxônia, processo que de certo convém mais aos minerais que contém somente prata que aos contém prata e ouro ao mesmo tempo, procederá aqui também por meio dela ao tratamento dos minerais, e confrontando-se a seu resultado com os da fundição acha-se que a fundição era incomparavelmente preferível, pois que em vez de perda se achava no fim do ano um excesso além do que os ensaios ou provas davam aos minerais. Era em Zalathna no tempo que o enigma se começa a datar. O Diretor da fundição fundia muito bem segundo as contas que ele faria sempre favoráveis ao Imperador; mas de fato fundia contra ele e com perda como todos os outros processos atuais. Acha-se em menos de um ano com uma perda cinquenta e dois marcos de ouro, perda extraordinária para quem não extraía pela fundição mais de cinco quintais por ano; e que ele deveria ter lançado sobre as contas de 10 ou 12 anos anterior a não ter quando passar pelo melhor fundidor da Hungria e suplantar aqui como pontada para a amalgamação.

Acha-se ainda que as escórias contenham mais que [ilegível] mais pobre de minerais que o Imperador recebe, e paga. O Diretor das fundições valia-se contra os dois fundidores, que o enganavam; dando-lhe um maior conteúdo que os minerais findam: os ensaiadores trabalham e provam que eles fundem mal, e posto seja muito difícil ensaiar com rigor minerais de ouro tão pobres, não lhes será quanto a mim difícil prová-lo. Procede-se atualmente a um balanço geral para concluir a perda real.

Tudo isto provém de um veio que escapou no estabelecimento da administração, quero dizer, de se não dar ao diretor da fundição um contraste ora fiscal, [ilegível] do que se viesse no conhecimento da bondade das [ilegível] o piraçõens; se tais vícios escapam em uma administração estabelecida em um país onde a extração das minas é tão antiga, que não deve acontecer naqueles onde esta é recém-nascida, ou está ainda para nascer.

Em geral a lavagem do ouro é bem preferível na Transilvânia a dos outros países, e os habitantes deste, que desde o tempo dos romanos lavaram ouro são extremamente hábeis 
nesta arte de trabalho. Ultimamente, o Diretor das máquinas de pilhar e de lavar os minerais construiu sua nova sorte de tábua de lavagem, que excede todas as construídas por ganhar por meio dela, em braços em tempo, em pureza de mineral. Sem todavia se perder mais do que se perdia por meio das outras concedidas em Hungria, onde sempre se lavou melhor que nos outros países (ilegível). Eu já ordenei modelos desta sorte de tábuas de lavagem, e de outras máquinas que achei poderiam ser úteis entre nós. Por muito felizmente me terei se do que venho de dizer, praticado entre nós, ver um dia a Sua Majestade e seus Estados. A minor beneficies.

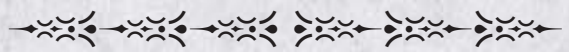

